\title{
Direito, Estado e Telecomunicações: a força gravitacional da banda larga (Apresentação)
}

Law, State and Telecommunications: The Broadband Gravitational Force

(Presentation)

\begin{abstract}
Resumo
O presente estudo figura como introdução à Revista de Direito, Estado $e$ Telecomunicações do Grupo de Estudos em Direito das Telecomunicações da Universidade de Brasília, abordando sinteticamente a estrutura, conteúdo e política editorial da revista. Em acréscimo, o texto analisa os principais acontecimentos do setor no Brasil, bem como normas e julgados relativos ao ano de 2010, para registro das principais discussões jurídico-políticas do setor de telecomunicações brasileiro referentes ao ano anterior ao da publicação.
\end{abstract}

\section{Abstract}

This text introduces the Law, State, and Telecommunications Review, addressing, by way of an overview, its structure, contents and editorial policy. Besides that, this introduction defines the underpinnings of the journal's regulatory approach. Statutes, administrative regulation and judicial decisions of 2010 pertaining to telecommunications are referred to in detail. It also addresses the main political and juridical discussions on the Brazilian telecommunications sector that took place in the previous year of this journal's edition.

Palavras-chave: RDET 2011; telecomunicações; regulação; banda larga; Brasil. Keywords: RDET 2011; telecommunications law; regulation; broadband; Brazil.

\section{Apresentação}

Em consonância com o propósito inaugural da Revista de Direito, Estado e Telecomunicações, apresenta-se o terceiro volume da publicação, mantendo-se a perspectiva de afirmação da revista como um instrumento de pesquisa jurídica setorial.

Para tanto, esta apresentação vai além da identificação das temáticas constantes da publicação e dá sequência ao registro histórico do arcabouço normativo setorial e do correspondente contexto socioeconômico e político das telecomunicações no Brasil. Este artigo introdutório também registra as principais discussões jurídico-regulatórias que marcaram o ano de 2010. 
O leitor se depara, em seguida, com o segundo tópico da revista, que corresponde à tradução para a língua portuguesa da petição 'Carterfone sem fio', de autoria da Skype, dirigida à Comissão Federal de Comunicações dos Estados Unidos - a Federal Communications Commission (FCC) -, em que os temas atualíssimos de neutralidade de redes móveis e do direito de conectar, rodar aplicativos e utilizar serviços da escolha do consumidor são problematizados. A aprovação das primeiras regras de neutralidade de redes móveis, nos Estados Unidos, no apagar das luzes do ano de 2010, reforça a importância histórica desta petição da Skype e dos argumentos nela levantados para aplicação do caso Carterfone às redes sem fio das empresas detentoras de infraestrutura essencial de transporte de telecomunicações móveis. O clássico caso Carterfone, em síntese, diz que qualquer equipamento do consumidor pode ser conectado às redes das carriers de telefonia fixa desde que não seja prejudicial à rede; a petição traduzida urge à FCC que ela aplique o princípio Carterfone às redes sem fio.

O terceiro tópico da revista é dedicado à apresentação de estudos selecionados que abordem questões jurídicas relevantes do setor de telecomunicações brasileiro. No presente número, o primeiro artigo desta seção é intitulado "O papel dos Pontos de Troca de Tráfego em políticas e regulação da banda larga", de Daniel Cavalcanti. Nele, chama-se a atenção para a importância estratégica da ação regulatória no incentivo de implementação de Pontos de Troca de Tráfego (PTT) abertos e neutros para ganhos de topologia e conectividade da internet e de redução de latência e custo da troca de tráfego nas modalidades de trânsito e de peering entre as redes de transporte [backbones] tradicionais das operadoras e os backbones construídos no bojo de planos nacionais de banda larga mediante investimentos em infraestrutura de redes de transporte para a internet. A problemática de ordem regulatória levantada no artigo enfrenta uma das questões mais agudas no que se refere à expansão do acesso à internet no Brasil, que consiste na alta concentração de redes de transporte e na ausência de mecanismos efetivos de garantia do acesso de Provedores de Acesso à Internet (PSI) às redes.

No artigo seguinte, intitulado "Mudança tecnológica e definição da agenda de políticas públicas: regulação para universalização da banda larga no Brasil", Cristiane Rauen enfatiza a indissociabilidade entre o componente fático tecnológico de informação e comunicação e a definição da agenda de Revista de Direito, Estado e Telecomunicações, v. 3, n. 1, p. 1-42 (2011)

DOI: https://doi.org/10.26512/1str.v3i1.21662 
políticas públicas setoriais, que dependem do contexto de avanço tecnológico e do constante reequacionamento da política pública de universalização/massificação da banda larga para garantia de que ela alcance todo o seu potencial quando em sintonia com as possibilidades técnicas disponíveis em seu tempo. Nele, os problemas originários das mudanças tecnológicas são enquadrados como janelas de oportunidades no processo de formulação da agenda política para definição de novas políticas públicas ou alteração de antigas.

$\mathrm{O}$ artigo de Guilherme Pinhero intitulado "The Brazilian Video Marketplace: A Regulatory Analysis and Perspective Under US Law" traz uma interessante comparação entre aspectos regulatórios dos meios de comunicação social eletrônica e de radiodifusão no Brasil e nos Estados Unidos, abordando, mediante cotejo da doutrina e julgados, os tópicos de neutralidade de redes, de cotas de conteúdo e da regulação de conteúdo eletrônico da internet, em batimento com a regulamentação dos serviços de TV a Cabo e radiodifusão. Em meio à elucidação de tais aspectos dos regimes jurídicos regulatórios das telecomunicações em ambos os países, a proposta central do estudo é a de evidenciar a presença de fundamentos suficientes para justificar a preservação de regimes jurídicos diferenciados entre radiodifusão e outros meios de comunicação social eletrônica, em especial, a internet, apesar dos efeitos unificadores da convergência no setor.

Renata Quelho, por sua vez, aborda, no artigo intitulado "A Lei Geral de Telecomunicações sob uma perspectiva convergente", a adaptabilidade da LGT a um contexto de convergência iluminado pelo conceito de modularidade e parametrizado pela pesquisa de dois cenários limitadores da convergência, quais sejam, a presença de ilhas na política de comunicação e a de silos no regime regulatório. O cerne do estudo consiste na identificação do grau de abertura normativa da LGT para possível migração de regulação em silos para uma regulação em camadas.

Finalmente, o último artigo deste volume intitulado "A fundamentalidade do direito à comunicação: internet e participação no contexto da sociedade em rede", de Pedro Felizola, é um estudo teórico compreensivo do encaixe entre políticas públicas de acesso à internet, sociedade-rede, desenvolvimento e direito fundamental à comunicação como um direito à informação de mão dupla apoiado no conceito de universalização de fruições essenciais, com o diferencial de se procurar 
definir pautas de políticas públicas de acesso à internet diretamente referidas ao binômio direito à comunicação - sociedade em rede, por intermédio do enfoque na paridade entre políticas educativas para uso da rede mundial de computadores e políticas estruturais de expansão da banda larga.

A seção em sequência aos estudos é dedicada ao registro de palestras e conta com a apresentação do então Coordenador do Programa de Inclusão Digital da Presidência da República, Cezar Alvarez, sob o título "Brasil conectado: o Programa Nacional de Banda Larga. Perspectivas para 20112014", em que são reveladas as posições governamentais sobre o andamento, objetivos e projeções do Plano Nacional de Banda Larga, bem como antecipadas as questões-chave para o Governo Federal, em especial o que denominou de temas tabus, de reestruturação do modelo regulatório de telecomunicações no Brasil até 2014 com relação, em especial, ao futuro da Telebras e à relação entre telefonia, redes de banda larga e universalização.

A quinta seção deste volume dedica-se ao registro do estágio em que se encontram temáticas atuais do setor de telecomunicações brasileiro traduzidas nos chamados informes setoriais. Os informes são registros do andamento de determinados temas relevantes ao setor de telecomunicações. Neste número da revista, encontram-se dois informes: a) o primeiro deles relativo às etapas próprias ao processo de coordenação e às regras caracterizadoras do direito de exploração de satélites, conforme praticados pela Administração brasileira junto a União Internacional de Telecomunicações (UIT); b) o segundo informe refere-se à atualização do informe setorial publicado no primeiro volume da Revista de Direito, Estado e Telecomunicações, em 2009, sobre a revisão quinquenal dos contratos de concessão do Serviço Telefônico Fixo Comutado (STFC), envolvendo o levantamento dos principais temas levantados durante as audiências públicas pertinentes.

Segue-se, na penúltima seção da revista, o registro de trabalhos acadêmicos selecionados, que foram apresentados no ano de 2010, na Universidade de Brasília, na pós-graduação em direito e em áreas afins reputados de interesse para o estudo jurídico do setor de telecomunicações.

Finalmente, a última seção da revista é dedicada à reunião das normas e julgados do setor de telecomunicações do ano de 2010 organizadas por temas e referenciadas a tabelas informativas. No início dessa seção, consta a lista de abreviaturas e siglas do setor de telecomunicações mantida pelo Revista de Direito, Estado e Telecomunicações, v. 3, n. 1, p. 1-42 (2011)

DOI: https://doi.org/10.26512/lstr.v3i1.21662 
GETEL/UnB, bem como, ao final, foi inserido um exaustivo índice alfabético e remissivo das normas e julgados do setor no ano de 2010. Cada tema presente em dita seção contém referências a julgados, a normas de todos os níveis e a atos administrativos correlatos.

\section{Filosofia da publicação}

A perspectiva orientadora da publicação consta de seu título como revista científica que reconhece a intercomunicação entre os papéis do Direito e do Estado no setor de telecomunicações. Mais ainda, a proposta de estudos jurídicos dirigida à interseção das rubricas estatal e telecomunicacional esboça uma concepção de direito regulatório em que o desenvolvimento setorial é visto como um empreendimento resultado da confluência de atores públicos e privados em meio a parâmetros jurídicos superiores responsáveis por sua classificação como um projeto público. Tem-se presente o princípio constitucional norteador da regulação setorial como um espaço de estudo do direito de liberdade política, que, dentre outras dimensões, incorpora ao verbo 'regular' a ação a ele correspondente de reconhecimento do dever do cidadão a aprender a se governar. O estudo do direito das telecomunicações tem por componente diretivo o significado do direito à autodeterminação e da virtude política.

Em outras palavras, a publicação não adota vieses predefinidos e, portanto, não se rende ao enfoque totalitário de esgotamento do sentido regulatório em mitos, sejam eles mitos assentados no fundamentalismo ou magia de mercado, sejam mitos assentados na suficiência do Estado. A presente publicação, como espaço de discussão e encontro de pontos de vista, encontra-se aberta a todas as correntes. Se não se pode defender a suficiência de um mercado destacado de fatores institucionais jurídicos, também não se pode defender o pressuposto da suficiência do planejamento macro e microeconômico, que restringe as decisões privadas do setor a partir de uma administração burocrática gerencial centralizada incapaz de se adaptar às demandas de uma sociedade da informação. Em nenhuma destas hipóteses, o princípio constitucionalista participativo encontra-se respeitado. Ele somente se apresenta em sua plenitude quando se reconhece a regulação como um espaço institucional regulador de exercício da 
liberdade de participação política por todos os atores setoriais habilitados a se responsabilizarem pelo presente e futuro das telecomunicações.

A presente publicação apresenta-se, portanto, como espaço público de discussão e confluência de todos os pontos de vista seriamente fundamentados e capazes de elevar o estado da arte da discussão jurídicoregulatória de telecomunicações.

\section{O setor de telecomunicações no ano de 2010}

Nada caracteriza melhor o ano de 2010 que a evidência de que nenhuma questão fundamental do setor de telecomunicações foge à força gravitacional da banda larga, apesar da reticência em declará-la uma infraestrutura ou um serviço essencial para exercício do direito à comunicação. ${ }^{1}$ Também foi o ano em que, por diversas razões de ordem institucional, o programa governamental de banda larga passou a ser discutido como um modelo de custo-benefício, esmaecida sua feição de ônus coletivo incorporado em um projeto de Estado de provimento de infraestrutura essencial necessária ao desenvolvimento.

\section{STFC e redes de suporte à internet: assimilação, confusão ou substituição?}

O ano de 2010 foi inaugurado com o requerimento dirigido à Comissão Federal de Comunicações (FCC) da maior operadora de telefonia norteamericana e herdeira do Sistema Bell - a AT\&T -, para que a agência reguladora de comunicações dos Estados Unidos se abstivesse de exigir a oferta de redes de telefonia fixa, argumentando-se que a morte do serviço seria uma questão de tempo. Segundo a AT\&T, a FCC deveria pensar em uma migração eficaz para o mundo da internet, pois as metas do Congresso norte-americano de acesso à banda larga seriam inviáveis se as empresas

${ }^{1}$ Em seu discurso de encerramento do $3^{\circ}$ Fórum Brasil Conectado, do Comitê Gestor de Políticas de Inclusão Digital, da Presidência da República, o coordenador do CGPID e assessor especial da Presidência, Cezar Alvarez, ao abordar a questão de política públicas de universalização da banda larga via obrigações dirigidas ao Serviço Telefônico Fixo Comutado, provocou a audiência ao perguntar se alguém poderia dizer, com segurança, se a banda larga seria um serviço ou uma infraestrutura. (Mariana Mazza. 'Não estamos alterando a telefonia fixa', diz Alvarez sobre metas de backhaul. In: Teletime News, de 30 de novembro de 2010, 20h32).

Revista de Direito, Estado e Telecomunicações, v. 3, n. 1, p. 1-42 (2011)

DOI: https://doi.org/10.26512/1str.v3i1.21662 
continuassem obrigadas as investir em redes de telefonia fixa. É bem verdade que essa movimentação empresarial não ocorreu impunemente, na medida em que o ano também caracterizou, nos Estados Unidos, a inauguração de uma postura ativa da FCC frente à internet ao reverter a antiga posição de afastá-la do gênero de serviços de telecomunicações, encerrando-se o ano com a inédita aprovação da regulamentação da neutralidade de redes móveis.

A centralidade da questão de (re)classificação jurídica da internet nos Estados Unidos é melhor vislumbrada no caso Comcast/Bittorrent, de 6 de abril de 2010. Dele resultou a clara consciência, por parte da FCC, da necessidade de uma posição firme do órgão regulador sobre a classificação jurídica da internet, ou ao menos, da infraestrutura de suporte da internet. A hesitação do órgão regulador dos Estados Unidos em reconhecer a essencialidade da infraestrutura de suporte à internet como um serviço submetido ao Título II do Communications Act de 1934 foi o principal motivo da perda da batalha judicial e consequente anulação da decisão $s u b$ judice da FCC, que vedava a discriminação de conteúdo na rede de banda larga da Comcast. A seguir, descreve-se a decisão da Corte de Apelações do Circuito do Distrito de Columbia, de 6 de abril de 2010, no caso Comcast $v$. $F C C$, para esclarecimento da questão jurídica de fundo.

Trata-se de caso em que se discutiu a internet aberta [open Internet], ou seja, a caracterização da internet como ambiente isento de discriminação. Nele, a Comcast apelou aos tribunais para declarar ilegal a vedação da FCC ao bloqueio implementado pela Comcast para aplicações de rede peer-topeer $^{2}$. A decisão do D.C. Court of Appels asseverou que a FCC não teria autoridade para regular as práticas de gestão da rede de um provedor de serviço de internet apoiada no poder da FCC de disciplinar atividades razoavelmente ancilares $^{3}$ às suas competências legais ${ }^{4}$ quando estas

${ }^{2}$ Os "programas de peer-to-peer permitem que seus usuários compartilhem diretamente grandes arquivos entre si sem a necessidade de passarem por um servidor central. Tais programas também consomem largura de banda significativa." (Tradução livre do original) Comcast Corporation v. Federal Communications Commission and United States of America, Case 08-1291 (D. C. Circuit Court of Appeals 2010).

${ }^{3}$ Os tribunais norte-americanos passaram a denominar a competência entregue à FCC pela Seção 4(i) do Communications Act de 1934 pelo termo 'autoridade ancilar' [ancillary authority]. A doutrina e a jurisprudência norte-americana derivam o termo 
estivessem apoiadas exclusivamente em políticas de governo declaradas pelo Congresso, que não atribuem competência legal [statutory legal responsabilities] à FCC. $\mathrm{O}$ argumento central para justificativa da atuação da FCC no uso de sua autoridade ancilar [reasonable ancillary authority], ao vedar a discriminação desarrazoada da rede de provedores de acesso à internet, está na assertiva de que dita vedação decorreria diretamente da autoridade da FCC de garantia de que o serviço de acesso banda larga à internet fosse "rápido" e "eficiente", nos termos da Seção I do Communications Act de 1934. O contra-argumento utilizado pela Comcast foi o de que tanto a Seção I, quanto a 230(b) do Código Federal dos Estados Unidos (U.S.C.) sobre proteção contra conteúdos ofensivos, não garantiriam a autoridade ancilar da FCC por serem meros enunciados legislativos de políticas públicas [congressional statements of policy] insuficientes para conferir competência legal à FCC de limitação das atividades comerciais correspondentes. A FCC falhou em demonstrar que sua decisão (Order) estava embasada em lei. A decisão da Corte, ao final, firmou o entendimento de que a atuação da FCC, no caso, extrapolava sua função ancilar, pois esta função seria incidental e dependente de poderes específicos delegados pelo Communications Act de 1934. Se a infraestrutura de suporte à internet fosse claramente definida pela FCC como matéria atinente aos serviços de telecomunicações propriamente ditos, tais limitações não se aplicariam. De um lado, dois conselheiros da FCC afirmaram (Clyburn indiretamente e Michael Copps diretamente) que essa seria a oportunidade de se reclassificar a banda larga como um serviço de telecomunicações; de outro, dois conselheiros (Baker e McDowell) declararam inadequada a intenção de se reclassificar a internet e os serviços de acesso à internet banda larga como serviços sob a regulação da era monopolística do Título II.

de três decisões da Suprema Corte dos Estados Unidos: a decisão United States v. Southwestern Cable Co., 392 U.S. 157 (1968); a decisão United States v. Midwest Video Corp., 406 U.S. 649 (1972) (Midwest Video I); e a decisão FCC v. Midwest Video Corp., 440 U.S. 689 (1979) (Midwest Video II). Por autoridade ancilar se entende a atribuição da Seção 4(i) de que "a Comissão [FCC] pode implementar quaisquer atos, aprovar tantos regulamentos e regras e editar tantas resoluções, desde que em sintonia com este capítulo, quantos forem necessários para execução de suas funções" (Tradução livre: 47 U.S.C. § 154(i)).

${ }^{4}$ Seção 4(i) do Communications Act de 1934; 47 U.S.C. § 154(i).

Revista de Direito, Estado e Telecomunicações, v. 3, n. 1, p. 1-42 (2011)

DOI: https://doi.org/10.26512/1str.v3i1.21662 
O contexto da decisão é ainda mais relevante, pois se confirma uma tendência que paulatinamente foi sendo instaurada nos EUA de se isentar a internet do tratamento normativo dispensado às detentoras de infraestrutura essencial de transporte [carriers] de telecomunicações, o que é bem representado na declaração do conselheiro da FCC, Michael Copps, a propósito da decisão: "Desde 2002, eu tenho advertido sobre os perigos de mover o componente de transmissão da banda larga para fora do arcabouço legal aplicável às empresas detentoras de infraestrutura essencial de telecomunicações". 5

Assim, o caso demonstra duas importantes facetas da questão regulatória envolvida: a) a falta de clareza na classificação da banda larga como telecomunicações pela FCC; b) a afirmação da posição da FCC de promoção de uma internet livre e aberta [free and open Internet] e, portanto, de sua natureza de interesse público.

A questão da natureza jurídica dos serviços da infraestrutura de suporte à internet permaneceu como um tópico central da agenda da FCC. No segundo semestre de 2010, foi a vez de se lidar com a neutralidade da rede móvel. Após sofrerem críticas severas do presidente da FCC - Julius Genachowski -, sobre suposto acordo para acesso e tráfego preferencial de dados da Google na rede da operadora de telecomunicações Verizon, ambas publicaram, no dia 9 de agosto de 2010, uma proposta para que se aprovasse uma lei sobre neutralidade de redes para a internet, em que se atribuiria poder regulador à FCC sobre a internet em banda larga e sobre as operadoras norte-americanas para a defesa dos direitos dos internautas americanos. Trata-se, portanto, da continuidade da discussão inaugurada formalmente pela Skype em sua petição traduzida neste volume.

No Brasil, por sua vez, a mesma questão sobre a natureza das redes de suporte à internet foi ambientada em outro contexto jurídico-político. No âmbito das obrigações de instalação de infraestrutura de rede de suporte ao

${ }^{5}$ Tradução livre do original: "Since 2002, I have warned about the dangers of moving the transmission component of broadband outside of the statutory framework that applies to telecommunications carriers. The only way the Commission can make lemonade out of this lemon of a decision is to do now what should have been done years ago: treat broadband as the telecommunications service that it is (...) We should straighten this broadband classification mess out before the first day of summer" (Declaração do Conselheiro Michael J. Copps sobre a decisão Comcast v. FCC, de 6 de abril de 2010). 
Serviço Telefônico Fixo Comutado (STFC), o regulamento do PGMU II - o anexo à Res. 539/2010, que regulamentou o PGMU aprovado pelo Decreto 4.769/2003, alterado pelo Decreto 6.424/2008 - previu o backhaul público como bem reversível, remetendo para a área técnica da agência a definição precisa de quais redes seriam objeto de reversão ao final dos contratos de concessão agendado para 2025.

Em outras palavras, a discussão sobre a convergência entre STFC e redes de suporte à internet foi traduzida, no Brasil, em termos jurídicos, na imprecisão regulatória quanto à extensão dos bens reversíveis dos contratos de concessão de STFC e nas tentativas frustradas da área técnica da ANATEL em ampliar a definição normativa do STFC, enquanto que, nos Estados Unidos, a discussão repercutiu no reposicionamento da FCC quanto à natureza jurídica da internet como serviço de telecomunicações.

O entendimento predominante, no Brasil, em 2010, foi o de que seriam utilizados como critérios para identificação dos bens sujeitos à reversão as capacidades de rede estipuladas no decreto de troca de metas - o Decreto 6.424/2008. Ou seja, somente o backhaul com capacidade de 8, 16, 32 e 64 Mbps construído a partir do decreto seria caracterizado como bem reversível. Ficou para um futuro terceiro plano, apelidado de PGMU III, o esclarecimento da plena equivalência financeira da substituição das antigas metas de universalização referentes à instalação de Postos de Serviço de Telecomunicações (PST) por infraestrutura de rede de suporte do STFC (backhaul), mas a proposta de redação do PGMU III submetida à consulta pública nasceu polêmica, quando, em setembro de 2010, o Conselho Consultivo da ANATEL criticou seu texto por introduzir metas cuja implementação somente seria esclarecida por regulamentos específicos futuros.

A dúvida sobre a real separação entre obrigações de universalização e infraestrutura de serviços privados no STFC foi agitada com nova petição na ação da ProTeste contrária à troca de metas de universalização do STFC por redes de suporte à banda larga (backhaul), na $6^{\mathrm{a}}$ Vara Federal da Seção Judiciária do DF, que reiterou requerimento ao juízo para nomeação de perito para avaliação da real natureza do backhaul e, em especial, para averiguação de subsídio cruzado entre o STFC público e os serviços de dados privados das concessionárias. A petição citada apoiou-se na afirmação de nota técnica da Anatel, no pedido de anuência prévia para compra da Revista de Direito, Estado e Telecomunicações, v. 3, n. 1, p. 1-42 (2011)

DOI: https://doi.org/10.26512/1str.v3i1.21662 
Brasil Telecom pela Oi, em 2008, em que se indicava que grande parte dos resultados obtidos pela Oi estaria sendo aplicado na rede de dados, ao invés de sua aplicação na rede de suporte ao STFC. O argumento da ProTeste firmou-se no fato de que, na medida em que as tarifas públicas do STFC estariam sendo usadas para subsidiar redes privadas das operadoras, não haveria mais razão para a existência de planos de metas de universalização para o STFC e que a criação de novo plano de metas de universalização para o backhaul teria a única intenção de "tentar legitimar o desvio ilegal de recursos do STFC para o financiamento de redes particulares de comunicação de dados". Em março de 2010, a juíza do caso determinou que se fizesse uma perícia técnica com peritos indicados pela Universidade de Brasília, Universidade de São Paulo e Universidade Estadual de Campinas nas redes das concessionárias para esclarecimento do alcance do backhaul e definição do que foi objeto da troca de metas de universalização para infraestrutura de suporte de acesso à internet.

Por outro lado, sob o ponto de vista de política pública de expansão do acesso à internet no Brasil, a ANATEL fez repercutir, na proposta de redação do PGMU III, a incorporação de metas de expansão da banda larga nos objetivos de serviço público de telefonia fixa. A apropriação, pela proposta de texto do PGMU III, de setembro de 2010, da meta de expansão de banda larga foi questionada pelo secretário geral da Telefônica no Brasil, na medida em que a meta não traria benefício ao STFC, mas a um serviço privado - o SCM -, questionando, portanto, o pressuposto da Anatel de que a rede de banda larga funcionaria como "suporte do STFC", fundamento este antes aceito pelas concessionárias quando da troca das metas de universalização de PST por backhaul.

A proposta de texto submetida à consulta não havia detalhado a forma de uso da capacidade de backhaul, que ficaria para futura regulamentação, muito embora a área técnica da Anatel já antecipasse que somente empresas de telecomunicações poderiam solicitar capacidade de backhaul e que ela dependeria da disponibilidade de cada empresa. Na audiência pública de apresentação da proposta do PGMU III válido de 2011 a 2015, em 20 de setembro de 2010, a Telefônica, por sua diretora de Assuntos Jurídicos Regulatórios, criticou a proposta, em especial, a exigência de oferta de backhaul por demanda dos interessados, ao invés de se exigir a oferta do backhaul onde ele não estivesse disponível. A reação às novas metas 
adquiriu uma feição tecnicista jurídica ao se defender, então, pela Telefônica, que a Anatel deveria respeitar o prazo legal de 24 meses do conhecimento das novas obrigações pelas concessionárias para sua implantação, o que exigiria que o PGMU III tivesse sido aprovado até 31 de dezembro de 2008 para sua aplicação a partir de $1^{\circ}$ de janeiro de 2011.

A discussão evidenciou o poder polarizador da banda larga no âmbito das obrigações de universalização do STFC. À medida que a regulamentação da Anatel absorvia a concepção de infraestrutura de suporte à banda larga (backhaul) como bem afeto ao serviço público de telefonia, cresciam as críticas. Em 18 de outubro, o SindiTelebrasil encaminhou carta ao Conselho Consultivo da Anatel, rechaçando a posição de inserção do backhaul como meta de universalização de serviço público e a perspectiva de se incluir definitivamente a banda larga como modalidade do STFC em regime público.

Em meio à discussão que dominou a agenda do setor no segundo semestre de 2010, decisões judiciais impediram a efetiva edição do PGMU III ao internalizarem a demanda por mais prazo para a consulta pública pertinente. Derrubada a primeira liminar de prorrogação da consulta pública em 4 de outubro de 2010, nova decisão em sede do TRF da $2^{a}$ Região prorrogou a consulta pública do PGMU III até $1^{\circ}$ de novembro, ameaçando inviabilizar a sua edição antes da renovação dos contratos de concessão prevista para 31 de dezembro de 2010 para o quinquênio de 2011 a 2015.

Em 13 de dezembro de 2010, em reunião dos presidentes de todas as concessionárias de STFC do país com o ministro das comunicações, José Arthur Filardi, e o seu anunciado sucessor, Paulo Bernardo, oficializou-se a proposta do Governo Federal de que, se as empresas abrissem mão de suas ações judiciais contra o PGMU III, seria postergada a edição do Decreto correspondente até que se chegasse a um acordo sobre os aspectos mais polêmicos, nomeadamente: a) custos e meios de financiamento das metas de universalização, que diferiam nas projeções da Anatel e de consultorias contratadas pelas empresas; b) metas de universalização em áreas rurais, em virtude do recente interesse de uso da faixa de $450 \mathrm{MHz}$ pela Telebras para expansão do acesso banda larga a áreas remotas, ameaçando a expectativa das empresas de utilizarem a faixa de $450 \mathrm{MHz}$ para cumprir suas obrigações de universalização em áreas remotas; e c) conceituação do backhaul, em especial, a precisão da fronteira entre o que seria público - e Revista de Direito, Estado e Telecomunicações, v. 3, n. 1, p. 1-42 (2011)

DOI: https://doi.org/10.26512/1str.v3i1.21662 
reversível à União ao final dos contratos - e o que seria privado na rede. Em 15 de dezembro, o SindiTelebrasil comunicou que teria protocolado os pedidos de desistência das ações judiciais movidas contra o PGMU III à espera do adiamento da edição do decreto veiculador para maio de 2011.

Ao fim e ao cabo, a resistência à eventual assimilação da banda larga como parte das obrigações de STFC em regime público ou de possível Serviço de Comunicação Multimídia (SCM) em regime público, embora fundadas em argumentos de natureza do serviço, expressaram o descontentamento das empresas com a equação econômica de compensação pela ampliação de metas no PGMU III, que, ao contrário da troca de metas de Postos de Serviço de Telecomunicações (PST) por backhaul então apoiada pelas concessionárias, não deixou claro, no memorial econômico, a compensação econômica às empresas.

Em outubro de 2010, o foco das discussões entre concessionárias e agência reguladora encontrava-se claramente no reequacionamento dos cálculos de custos da expansão do backhaul em conjunto com a crescente demanda das concessionárias por garantia de fontes externas de financiamento da universalização. Do mesmo modo, o fundamento jurídico da natureza do serviço de infraestrutura de banda larga foi colocado como instrumental à eliminação, por parte da Associação Brasileira de Defesa do Consumidor (ProTeste), do prejuízo ao usuário de STFC no custeio de serviço distinto da telefonia e apropriação de benefícios econômicos pelas empresas ao se justificar a manutenção da tarifa de telefonia nos níveis de então para cobertura dos gastos previstos com a ampliação do backhaul. O argumento básico da ProTeste foi o de que o Governo Federal e a Anatel estariam desvirtuando o STFC ao ampliar o seu escopo para a banda larga, dificultando ainda mais a universalização da telefonia. A proposta de uma "bolsa telefone", que consistiria na destinação do Acesso Especial Classe Especial (AICE) para beneficiários de programas de assistência governamental como o "bolsa família", no esboço de discussão do PGMU III, também foi criticada pela ProTeste ao significar a transformação de um dever indiscriminado de universalização em assistencialismo estatal. Dita proposta não vingou, entretanto. A proposta da ProTeste, por sua vez, era a de que, ao invés de se criarem camadas de diferenciação de usuários por renda, discriminação esta vedada pela Lei Geral de Telecomunicações (Lei 9.472/97), cumprir-se-ía o equilíbrio econômico-financeiro dos contratos de 
concessão de STFC pela repercussão da diminuição dos custos de metas de universalização de PST no valor do plano básico de telefonia, mediante adoção de tarifa flat de $\mathrm{R} \$ 14,00$ com ligações ilimitadas locais.

Em ambas as posições, fosse das concessionárias, fosse dos usuários/consumidores, o fundamento encontrava-se nos efeitos econômicos da regulação e não na discussão de fundo sobre a natureza jurídica da banda larga. Nos moldes em que foi desenhada a discussão, a natureza jurídica da banda larga no Brasil tem dependido muito mais do esclarecimento da compensação econômica do que da averiguação da essencialidade da banda larga para um projeto brasileiro de revolução informacional.

Em novembro de 2010, a Anatel firmou o entendimento técnico de que o equilíbrio econômico-financeiro exigível no processo de reequacionamento das metas de universalização não se aplicaria a cada meta, mas ao contrato de concessão como um todo, esclarecendo que o equilíbrio econômicofinanceiro dos contratos não se confundiria com o equilíbrio de metas de universalização. Vale dizer, no cômputo do equilíbrio contratual, vale o saldo geral de todas as metas frente a seus custos, ao invés de se exigir saldo zero para cada meta. Esta posição é coerente com o princípio de equilíbrio econômico-financeiro, decorrente da natureza sinalagmática do contrato administrativo temperada com a supremacia do interesse público.

Em outra frente instrumental à solução do questionamento sobre a natureza jurídica do backhaul, a Superintendência de Serviços Públicos deu um passo além na antiga intenção de ampliação do conceito de STFC para além da limitação regulamentar de $64 \mathrm{kbps}$ e em cumprimento à meta de curto prazo de adequação da regulamentação do STFC ao cenário convergente contida no item V.5 do Plano Geral de Atualização da Regulamentação das Telecomunicações no Brasil (PGR), quando submeteu ao Conselho Diretor da Anatel, em outubro de 2010, proposta de alteração do regulamento do STFC, sob o fundamento de preservação da atualidade do serviço e de recuperação de sua atratividade econômica e comercial. Na mesma iniciativa, voltou à tona a sugestão de retirada da referência conceitual ao STFC como comunicação entre pontos fixos. Ao final, a proposta de alteração do Regulamento do STFC aprovada na última reunião do Conselho Diretor da Anatel, em 16 de dezembro de 2010, para submissão à consulta pública, não contemplou a alteração do conceito de processos de telefonia, dificultando ainda mais a reconciliação textual entre as Revista de Direito, Estado e Telecomunicações, v. 3, n. 1, p. 1-42 (2011)

DOI: https://doi.org/10.26512/1str.v3i1.21662 
disposições normativas de alastramento da utilidade do STFC em regime público para fazê-lo abarcar a crescente essencialidade da rede de banda larga. A conciliação dos princípios norteadores do regime público e da essencialidade da internet e de sua infraestrutura de suporte (backhaul) mais e mais depende da capacidade interpretativa da Anatel e dos tribunais.

Em diversos eventos do setor, em 2010, representantes das concessionárias frisaram a natureza reversível da rede de telefonia em oposição à natureza privada da rede de banda larga das empresas. Em 24 de novembro de 2010, o conselho diretor da Anatel votou o texto do contrato de concessão para o quinquênio de 2011-2015, incluindo a definição de processo de telefonia, sob protestos de representantes das operadoras presentes à sessão pública de votação. $\mathrm{O}$ aspecto que mais chamou a atenção, entretanto, no novo texto do contrato, foi a introdução da possibilidade de abatimento dos custos das metas de universalização da taxa bianual de $2 \%$ do faturamento bruto das operadoras pago a título de preço público de concessão, remetendo-se a compensação dos custos da concessão não mais à regulamentação da Anatel, mas a decreto presidencial, presumivelmente de aprovação do novo Plano Geral de Metas de Universalização (PGMU III).

A remissão a decreto presidencial teria decorrido da insatisfação manifestada pelo Ministério da Fazenda quanto à solução encontrada pela Anatel para dar maior margem de manobra à composição da equação econômico-financeira do contrato frente às metas de universalização. A possibilidade de desconto dos custos com a universalização nas parcelas bianuais dos preços das licenças de STFC foi inserida acompanhada do esclarecimento de que, para além das receitas obtidas com a prestação do STFC, as receitas operacionais geradas a partir da interconexão e de outros serviços acessórios das concessionárias classificados como de prestação, utilidade e comodidade (PUC) também fariam parte da base de cálculo do preço da concessão. Com isso, o método de cálculo do preço público devido em razão das concessões de STFC passa a se alinhar com a base de cálculo do Fundo de Universalização dos Serviços de Telecomunicações (FUST). O fundamento jurídico então referido nas falas dos representantes das concessionárias, na sessão pública de votação dos novos contratos, foi o de que a revisão quinquenal seria essencialmente distinta em seus efeitos da revisão dos contratos de concessão, vedada, no dizer das empresas, qualquer 
tipo de alteração em cláusulas econômicas. Esta argumentação coloca em xeque, todavia, o esperado desconto no ônus da concessão para ampliação de metas de universalização capitaneadas pelas obrigações de backhaul.

\section{O Plano Nacional de Banda Larga (PNBL)}

Os primeiros meses do ano de 2010 representaram o desfecho do processo de produção do documento-base do Plano Nacional de Banda Larga (PNBL). A equipe responsável pelo plano apresentou ao presidente Lula cenários de preços pela oferta de banda larga de $512 \mathrm{kbps}$, concluindo que o cenário mais vantajoso em termos de custo-benefício para o Estado consistiria na restrição da empresa estatal à oferta de rede no atacado. Finalmente, em 19 de fevereiro de 2010, o presidente Lula publicamente afirmou que a Telebras seria "recuperada" para "fazer banda larga nesse país".

As reuniões governamentais para definição do PNBL se arrastaram até abril de 2010, quando um tópico pareceu polarizar o debate: a viabilidade econômica da prestação direta de serviços de acesso banda larga pela Telebras ao consumidor. Em discussão, na Comissão de Ciência e Tecnologia, Comunicação e Informática, da Câmara dos Deputados, no final de abril, o presidente da Abrafix, José Fernandes Pauletti, quis deixar claro que o serviço em regiões desatendidas certamente seria deficitário e que se garantisse que, caso a Telebras operasse o PNBL, que o fizesse em igualdade de condições com as empresas privadas. A descrença na lucratividade em regiões desatendidas provocou a reafirmação, por parte do Secretário de Logística e Tecnologia da Informação do Ministério do Planejamento, Rogério Santanna, de que o que garantiria a lucratividade seria o investimento em inovação.

A par da polêmica sobre a potencial lucratividade da Telebras, a declaração do futuro presidente da estatal de que o governo necessitaria de um instrumento para influenciar o comportamento das empresas no setor é, sem dúvida, a mais significativa: "É preciso ter uma ferramenta de pressão. Se as empresas acharem que o governo é um leão sem dentes, as empresas ficarão na zona de conforto".

Enfim, o PNBL em discussão na Casa Civil caracterizou-se como um projeto abandonado pelo Ministério das Comunicações, atacado pelo Ministério da Fazenda na utilização da Telebras e pelas empresas do setor 
em tudo que dissesse respeito à prestação direta de serviços de banda larga ao consumidor e festejado pelo Ministério do Planejamento, pela Casa Civil e pela Secretaria de Assuntos Estratégicos da Presidência da República.

O Presidente da República, por sua vez, levou-o a tira-colo e discursou em diversas ocasiões em sua defesa, dando-lhe o merecido peso político, mas o PNBL foi paulatinamente sendo minado pela ausência de decisão política presidencial sobre suas linhas gerais. $\mathrm{O}$ atraso no seu lançamento levou à sua notável ausência no Programa de Aceleração do Crescimento (PAC2) anunciado em 29 de março de 2010: um programa de crescimento em plena sociedade da informação sem referência à banda larga.

Em outra frente, a estratégia do Ministério das Comunicações, que contou com apoio do PMDB, concretizou-se no lançamento, no início de 2010, da reestruturação da Empresa de Correios e Telégrafos (ECT) com proposta de ampliação de escopo para colocá-la no páreo para gestão do PNBL.

Em março de 2010, nos EUA, foram divulgadas as metas do seu plano de banda larga. A análise das medidas nele previstas e da integração de diferentes instâncias governamentais em uma frente comum, bem como a presença de práticas institucionais consolidadas de investimento na universalização dos serviços de telecomunicações daquele país (US\$17,1 bilhões gastos anualmente em fundos de conectividade) esboçam a dimensão comparativa do imenso esforço necessário para preencher o vazio de cultura política institucionalizada para o fim de universalização dos serviços de telecomunicações no Brasil.

Finalmente, em 5 de maio de 2010, o PNBL foi oficialmente divulgado em entrevista coletiva de Cesar Alvarez, aguardando a publicação do decreto pertinente - o Decreto 7.175, de 12 de maio de 2010. O PNBL foi anunciado com quatro pilares básicos e sem modificações significativas ao que vinha sendo anunciado pela equipe responsável por sua organização desde sua divulgação em novembro de 2009: a) revitalização da Telebras; b) consolidação de uma rede estatal que funcionaria como alternativa concorrencial no mercado com oferta prioritária no atacado e possibilidade de prestação direta ao usuário final onde não houvesse interesse da iniciativa privada, mediante meta de preço de $\mathrm{R} \$ 35,00$ no serviço ao público e preço no atacado de $\mathrm{R} \$ 230,00$ por $1 \mathrm{Mbps}$; c) política industrial para a área tecnológica; d) desonerações fiscais e de encargos. 
Além disso, a Telebras foi imbuída da função de empresa responsável pela implementação da capacidade de banda larga para a Administração Pública federal e pelo suporte a políticas públicas de conexão a internet em universidades, centros de pesquisa, escolas, hospitais, telecentros comunitários e pontos de interesse público. Em fato relevante do dia 4 de maio de 2010, enviado à Comissão de Valores Mobiliários (CVM) pela Telebras, esta definiu o seu papel no PNBL com a função de: a) implementar a rede privativa de comunicação da Administração Pública federal; b) prestar apoio e suporte a políticas públicas de conexão à internet em banda larga para universidades, centros de pesquisa, escolas, hospitais, postos de atendimento, telecentros comunitários e outros pontos de interesse público; c) prover infraestrutura e redes de suporte a serviços de telecomunicações prestados por empresas privadas, Estados, Distrito Federal, Municípios e entidades sem fins lucrativos; e d) prestar serviço de conexão à internet em banda larga para usuários finais, apenas e tão somente em localidades onde inexistisse oferta adequada daqueles serviços.

A divulgação do PNBL apoiado na reativação da Telebras serviu de mote à divulgação de nota à imprensa, por parte do SindiTelebrasil, que congrega as principais operadoras de telecomunicações do país, enfatizando que os investimentos até então feitos pelas operadoras de telecomunicações exigiriam que a reativação da Telebras respeitasse o quadro de igualdade de tratamento das empresas de telecomunicações no país, rechaçando a possibilidade de entrada de um concorrente no mercado com tratamento privilegiado e enfatizando a necessidade de redução da carga tributária sobre o setor.

O aspecto interessante do processo de discussão sobre os limites de ingerência do Estado na prestação direta de infraestrutura de suporte à banda larga foi evidenciado na assunção, por parte dos defensores do PNBL sediados no Governo, da justificativa de necessidade do Estado neste setor para garantia não somente do acesso, em si mesmo, mas para tomá-lo como um requisito fundamental para diversos programas de governo e metas de desenvolvimento nacional. É sintomática a referência de Rogério Santanna, então Secretário de Logística e Tecnologia da Informação do Ministério do Planejamento e futuro presidente da Telebras, em artigo publicado na Folha de São Paulo, no dia seguinte à divulgação do PNBL, à dependência entre a meta governamental de garantia de aposentadoria em até 30 minutos e a Revista de Direito, Estado e Telecomunicações, v. 3, n. 1, p. 1-42 (2011)

DOI: https://doi.org/10.26512/1str.v3i1.21662 
presença de banda larga em todos os municípios brasileiros. No mesmo tom, a então ministra-chefe da Casa Civil afirmou, ao abrir a entrevista coletiva de lançamento do PNBL concedida pela Presidência da República, Casa Civil e Ministério do Planejamento, de que a premissa fundamental em que a iniciativa estaria ancorada seria a de se configurar em um "projeto de desenvolvimento do país" com a meta de 40 milhões de domicílios com banda larga no Brasil até 2014, partindo de 12 milhões, no fechamento do ano de 2009 entre acessos fixos e móveis 3G.

O PNBL, enfim, foi lançado com o discurso oficial de retorno do Estado ao mercado de telecomunicações para fomento da concorrência com diminuição do escopo da Telebras para oferta de banda larga, ao invés da oferta e comercialização de serviços de telecomunicações em geral, mediante a injeção de recursos ou reativação das fibras óticas da antiga Eletronet, acrescida de cabos da Eletrobrás, Eletrosul, Eletronorte, Chesf e Petrobrás para composição da rede estatal, que seria ampliada com a projeção de criação de dois anéis para cobertura das capitais brasileiras e imediações até 2014 - o Anel Sudeste e o Anel Nordeste - tendo como centro de interligações a capital do país.

O lançamento dos editais para compra de equipamentos de rede e operação das fibras foi um evento merecedor de destaque no setor, no segundo semestre de 2010, com investimentos totais previstos até 2014 de 5,7 bilhões de reais e injeção do Tesouro limitada aos primeiros três anos de operação.

Coincidindo com os holofotes atraídos pela Telebras no primeiro semestre do ano de 2010, uma decisão do TCU, de 20 de janeiro de 2010, relatada pelo ministro Raimundo Carreiro, cancelou a contratação pela Telebras de empresa de serviços especializados, determinando a retomada dos funcionários cedidos da estatal para se evitar a contratação de serviços que o próprio corpo técnico seria capaz de executar, com prazo para retomada dos empregados até 31 de dezembro de 2010.

Na semana seguinte ao lançamento do PNBL, de início de maio de 2010, em carta encaminhada ao presidente da Anatel pela Abrafix, a associação solicitou que se tomassem "medidas cabíveis" para "garantir a separação entre a função reguladora do Estado e a sua atuação direta como Estado empresário" no que diz respeito à reintegração de parte dos mais de 170 funcionários da Telebras cedidos à Anatel e presentes na agência em 2010. 
Como era de se esperar, a discussão mais difícil de andamento e prioridades do PNBL ficou em segundo plano, sendo dominada pelos ataques à reativação da estatal sob o argumento de que, com isso, haveria vazamento de informações sigilosas das empresas de telecomunicações para um novo concorrente estatal, apesar de se tratar de concorrente com plano de negócios aberto ao público e antecipado pelas provisões do PNBL. A deficiência dos argumentos contrários à retomada de empregados da Telebras atuantes no âmbito da Anatel evidenciou-se na inconsistência em se ponderar um possível vazamento de informações sigilosas das empresas por empregados cedidos da Anatel, quando a empresa acolhedora teve seus planos de atuação previamente inscritos nas finalidades públicas de sua reativação.

Concretizada a reativação da Telebras, as atenções foram dirigidas, no segundo semestre do ano, ao significado da expressão "oferta adequada" de serviços de banda larga como condição para atuação direta da empresa na prestação de serviços ao consumidor.

O fechamento do ano, finalmente, presenciou a judicialização do desconforto empresarial com a reativação da estatal, em ação proposta na Justiça Federal do Rio de Janeiro, em novembro de 2010, impugnando-se a decisão governamental de classificação da Telebras como operadora única do PNBL. Em suma, os argumentos jurídicos levantados pelo Sindicato Nacional das Empresas de Telefonia e de Serviço Móvel Celular e Pessoal (SindiTelebrasil) defendiam a separação entre as funções reguladora e empresarial do Estado brasileiro e a garantia da isonomia de tratamento dos atores setoriais e da competição no mercado de telecomunicações, aplicando-se tal raciocínio inclusive a programas governamentais de universalização.

No que concerne à implementação do PNBL, dentre as várias atividades planejadas e a realização dos Fóruns Brasil Conectado, o Comitê Gestor de Políticas de Inclusão Digital (CGPID), da Presidência da República, definiu o valor de US\$ 40 milhões como valor de indenização às despesas a serem suportadas pela Polícia Federal, Petrobrás e outras empresas detentoras de autorizações de Serviço Limitado Móvel Privado (SLMP) frente à iminente desocupação da faixa de $450 \mathrm{MHz}$, em cumprimento a uma das metas do Plano Nacional de Banda Larga (PNBL) para a telefonia rural, planejandose a transposição das operações das entidades atingidas para a faixa de 380 Revista de Direito, Estado e Telecomunicações, v. 3, n. 1, p. 1-42 (2011) DOI: https://doi.org/10.26512/lstr.v3i1.21662 
MHz, o que, de fato se consolidou com a edição natalina das resoluções 556, 557 e 558, todas de 20 de dezembro de 2010, da Anatel.

\section{Mídia eletrônica: medidas anticoncorrenciais e o livre fluxo de informação}

Em outra frente, o ano de 2010 presenciou o recrudescimento das tensões entre a mídia tradicional, ou a nova mídia, e a mídia eletrônica, tanto no que concerne à reação das operadoras tradicionais à entrada de serviços de oferta televisiva via internet, quanto no que se refere aos limites de aplicação da regulamentação tradicional de liberdade de imprensa à internet.

Nos Estados Unidos, a indústria de vídeo online inaugurou o ano como centro de atenções de investigações antitruste em virtude de acusações, por parte de entidades civis, de que o serviço "TV Everywhere", mantido pela Comcast, Time Warner Cable, AT\&T, Verizon e Direct TV, estaria prejudicando a concorrência da pujante indústria de vídeo online representada pela Apple, Hulu, Boxee e Vuze. A associação Free Press e outros grupos de defesa da liberdade de imprensa enviaram cartas ao Departamento de Justiça (DoJ) e à Comissão Federal do Comércio (FTC), solicitando que se iniciasse um procedimento investigativo sobre os planos de cabo, satélite e de rede telefônica do serviço "TV Everywhere", acusando-o de, ao comercializar shows e filmes para computadores e outros dispositivos integrados à rede banda larga, acabariam por condicionar o acesso à prévia assinatura a ambos os serviços de televisão e de internet banda larga (Washington Post, de 4 de janeiro de 2010).

A própria mídia internacional esteve muito mais ocupada, em 2010, com um evento inédito, que tornou aparente o até então potencial impacto da internet nos moldes de seleção e veiculação de informações jornalísticas quando do vazamento de comunicados do Departamento de Estado dos Estados Unidos pelo sítio eletrônico Wikileaks. O fato chamou a atenção para os limites da regulamentação da imprensa na era da internet, dando nova dimensão ao antigo princípio do livro fluxo de informação [free flow of information], suscitado nas disputas geopolíticas leste-oeste da década de 1960, em meio à Guerra Fria, e reformatado pelo ingresso das nações não alinhadas na discussão, na década de 1970, mediante acréscimo da dimensão geopolítica norte-sul de demanda por uma nova ordem mundial de 
informação e comunicação (New World Information and Communication Order $-N$ WICO). ${ }^{6}$

\section{Revisão do marco regulatório da mídia}

Em 7 de outubro, o ministro-chefe da Secretaria de Comunicação Social da Presidência da República, Franklin Martins, anunciou que proporia, até início de dezembro, anteprojeto para a área de comunicação, em que incluiria a criação de uma agência reguladora para fiscalização do setor inspirado na regulação presente na Europa e nos Estados Unidos, descartando, de antemão, a ideia que chamou de ficção de que proporia a criação de um tribunal da mídia.

A discussão sobre a reformulação do marco regulatório da mídia com olhar sobre as mídias eletrônicas e a convergência entre radiodifusão e telecomunicações foi finalmente inaugurada de forma estruturada, no Brasil, em seminário realizado nos dias 9 e 10 de novembro de 2010, organizado pela Secretaria de Comunicação Social da Presidência da República, intitulado "Seminário Internacional das Comunicações Eletrônicas e Convergência de Mídias", voltado à discussão de modelos regulatórios de comunicações eletrônicas em países selecionados - Estados Unidos, França, Portugal, Espanha, Argentina e União Europeia como um todo.

Entre outros temas, foram apresentados os modelos regulatórios de mídia de diversos países. O objetivo do seminário foi abertamente definido como o de recolhimento de experiências internacionais selecionados sobre a política de convergência de mídias, assim entendida, a indiferença, para o usuário, da natureza do sinal recebido, seja radiodifusor ou não.

Como móvel central para realização do seminário, encontrava-se o reconhecimento, pelo ministro da Secretaria de Comunicação Social da Presidência da República, da urgência em se atualizar e preencher lacunas da legislação sobre comunicações, em especial, o evidente descompasso entre a normatização segmentada do setor frente à convergência e o notável silêncio histórico do legislador infraconstitucional em regulamentar os dispositivos constitucionais pertinentes à comunicação. Encerrou-se o seminário com a divulgação, pelo ministro da Secretaria de Comunicação

${ }^{6}$ Cf. CARLSSON, Ulla. The Rise and Fall of NWICO: From a Vision of International Regulation to a Reality of Multilevel Governance. In: Nordicom Review 2: 31-68, 2003.

Revista de Direito, Estado e Telecomunicações, v. 3, n. 1, p. 1-42 (2011)

DOI: https://doi.org/10.26512/lstr.v3i1.21662 
Social da Presidência da República (Secom), Franklin Martins, de princípios gerais de regulação do setor de mídia a serem contemplados em anteprojeto de lei de comunicação em preparação para submissão a consulta pública: promoção do estímulo à concorrência e competição; estímulo à inovação; respeito ao direito do cidadão e dos usuários; respeito à privacidade; proteção de menores; proteção da cultura; e proteção da produção nacional.

$O$ delicado tema da fronteira entre censura e regulação foi então remetido à prática mundial corriqueira de disciplina de parâmetros de proteção do vernáculo, e do equilíbrio, imparcialidade e proteção do menor.

Algumas afirmações pinçadas das falas dos palestrantes merecem ser transcritas a título de registro e com o fito de servir de esboço do significado geral do evento por meio de suas afirmações representativas: "sem regulação, não se estabelecem regras claras para atuação dos atores setoriais" (Franklin Martins, ministro da Secretaria de Comunicação Social da Presidência da República); “ou se produz um novo marco regulatório, ou nós vamos perder o bonde de uma área crucial da economia, e mais, para o exercício da cidadania" (Franklin Martins); "nenhum grupo tem o poder de interditar a discussão" (Franklin Martins); "se não houver um processo de discussão público, aberto e transparente, que coloque na mesa os interesses legítimos de cada um, e se resolva à luz dos interesses nacionais, quem vai regular não é o debate, nem o congresso; quem vai regular é o mercado, e quando o mercado regula, quem ganha é o mais forte" (Franklin Martins); "se não houver a criação de mecanismos que entendam a importância da radiodifusão e sua importância social no país, ela será atropelada pelas telecomunicações” (Franklin Martins); "a liberdade de imprensa não está em jogo" (Franklin Martins); "a liberdade de imprensa é mais do que a liberdade de imprimir; ela envolve a liberdade de divulgar" (Franklin Martins); o regulador "tem o poder de gerar renda em certos níveis (...) [mas] deve ser responsável perante o público" (Wijayananda Jayaweera, diretor da Divisão de Desenvolvimento da Comunicação e do Programa Internacional da Unesco para o Desenvolvimento da Comunicação); o regulador "deve assegurar de forma plural e eficiente a liberdade de expressão, programação e acesso ao público em geral, com a função-chave de assegurar o pluralismo na área de emissoras, diversidade de conteúdo, cobertura geográfica, nacional e regional, reconhecido como instrumento social que não pode se concentrar nas mãos de poucos" (Wijayananda 
Jayaweera); o regulador "deve assegurar o desenvolvimento das mídias comunitárias" (Wijayananda Jayaweera); "a alocação de frequência deve ser participativa ao invés de ser submetida a leilão para que o interesse público figure como aspecto central" (Wijayananda Jayaweera); "hoje o regulador deve dar atenção não somente à oferta de mídia, mas da demanda da mídia" (Wijayananda Jayaweera); "liberdade de expressão é fundamentalmente a livre circulação de informações e muitas vezes os Estados precisam intervir nesse sentido" (Toby Mendel, diretor executivo da ONG canadense Centro de Direito e Democracia [Center for Law and Democracy]); "o vídeo on demand é um universo pertencente à TV, e não à internet" (Emanuel Gabla, conselheiro do Conselho Superior do Audiovisual francês [Conseil Supérieur de l'Audiovisuel - CSA]); "os reguladores da OCDE estão adotando uma postura mais pragmática de planejamento da estrutura do mercado de TIC (...) com investimento estatal em infraestrutura pública para venda de capacidade de rede no atacado (...) exemplificativamente, Reino Unido, Suécia, Polônia, Grécia e Itália" (Dimitri Ypsilanti); "não sei se haverá convergência, colisão ou colisão convergente" (José Amado da Silva, presidente da Autoridade Nacional de Comunicações de Portugal ANACOM); "a internet móvel é a que mais irá colidir com os interesses tradicionais dos radiodifusores" (José Amado da Silva); "temos a tendência de achar que temos a propriedade do espectro, quando somente temos uma licença de uso" (José Amado da Silva); "porque o Brasil quis esta diversidade tão homogênea?" (José Amado da Silva, ao comentar a impropriedade de tratamento homogêneo do espectro em todas as regiões do Brasil); "o regulamento da União Europeia permite, e bem, as especificidades de cada país e acho que o Brasil tem espaço para estas especificidades todas e mais a Amazônia" (José Amado da Silva, ao salientar que o Brasil não deveria perseguir um tratamento regulatório uniforme para todo o seu território, quando se trata de distribuir espectro em regiões como a Amazônica para os serviços móveis versus outras regiões do país, em que os serviços cabeados teriam condições de suprir parte da demanda); "deve haver uma regulação convergente, mas é necessário uma regulação convergente ou a convergência dos reguladores?" (José Amado da Silva); "a abordagem de um regulador de conteúdos não pode ser nunca igual a de um regulador de telecomunicações" (José Alberto de Azeredo Lopes, presidente do Conselho Regulador da Entidade Reguladora para a 
Comunicação Social, de Portugal); "a abordagem dominante de um regulador de conteúdos é de cidadania" (José Alberto de Azeredo Lopes); “a ideia de uma liberdade sem limites é antítese da ideia de liberdade" (José Alberto de Azeredo Lopes); "a liberdade de imprensa é instrumental à liberdade de expressão (...) a regulação da mídia é sobre órgãos de comunicação social; não sobre jornalistas" (José Alberto de Azeredo Lopes); "grande parte das competências do regulador de conteúdos não é para defesa do consumidor, mas para proteção da liberdade de imprensa" (José Alberto de Azeredo Lopes); "a perspectiva do legislador português é tanto quanto possível transferir as competências do atual regulador de conteúdo para uma autorregulação (...) se perguntarmos a 100 jornalistas e patrões se são favoráveis à autorregulação, teremos 120 respostas favoráveis, mas este amor pela autorregulação é um amor platônico" (José Alberto de Azeredo Lopes); "não considero (...) que a liberdade de expressão permita a prática de atos anônimos pela internet" (José Alberto de Azeredo Lopes); "o regulador também tem que ter muito cuidado para não deixar espalhar-se o mito do cidadão jornalista (...) os órgãos de comunicação têm uma função e responsabilidade social com aquilo que lemos (...) se aceitamos que o mundo é feito de jornalistas, declaramos a morte da imprensa" (José Alberto de Azeredo Lopes); "é um grande erro pensarmos que existam modelos que devam ser copiados; devemos aprender sim com os erros dos demais" (Ángel García Castillejo); "na França, a transição da TV analógica para a digital será finalizada no final de 2011 (...) e estamos procurando manter essa forma gratuita de distribuição com interação ou em alta definição para que não seja a mesma da distribuição a cabo" (Emmanuel Gabla, comissário do Conselho Superior de Audiovisual da França [Conseil Supérieur de l'Audiuvisuel - CSA]); "a partir de 2004, a França adotou uma lei que finalmente reagrupou os setores de audiovisual e de telecomunicações" (Emmanuel Gabla); "o CSA já pôde intervir em um caso de transmissão audiovisual pela internet” (Emmanuel Gabla); “o serviço de vídeo sob demanda ingressou no âmbito das competências do CSA a partir de março de 2009" (Emmanuel Gabla); "os provedores de conteúdo, entretanto, estão excluídos da regulação pelo CSA" (Emmanuel Gabla); "a informação não pode estar confinada a somente aqueles que têm condições de pagar por ela" (Emmanuel Gabla); "temos presenciado a convergência em nível de plataforma, serviços, equipamentos e indústria" 
(Vincent Edward Affleck - diretor internacional do Office of Communication - OFCOM inglês para a ITU e a OCDE); "recebemos financiamento de taxas de licenciamento, mas temos que repassar muito deste dinheiro para o erário" (Vincent Edward Affleck); "hoje, todos os departamentos estão sofrendo cortes drásticos de recursos e pessoal" (Vincent Edward Affleck); "nossas decisões estão sujeitas ao Tribunal de Apelação inglês (...) fazemos pesquisas divulgadas ao público (...) nossa principal obrigação é garantir que, no Reino Unido, haja ampla gama de serviços eletrônicos (...) inclusive, proteção de material ofensivo de programação, invasão de privacidade, uso eficaz do espectro" (Vincent Edward Affleck); "não somos responsáveis por disputas entre operadores e consumidores" (Vincent Edward Affleck); "não estamos encarregados da internet, embora haja uma autorregulação sobre pornografia infantil" (Vincent Edward Affleck); "um dos nossos mais importantes objetivos é reduzir e simplificar a regulamentação" (Vincent Edward Affleck); "temos o projeto de utilizar, para a próxima geração de acesso à banda larga de até 100 Mbps, cerca de 2,5 bilhões de libras ao longo dos próximos 3 a 4 anos para oferta de serviços de banda larga por fibra ótica a 2/3 da população" (Vincent Edward Affleck); "quanto à regulação do conteúdo, adotamos objetivos de qualidade, pluralidade e proteção, mediante um conjunto de regras e cotas" (Vincent Edward Affleck); "quando outorgamos uma licença, ela não está vinculada a uma plataforma determinada" (Vincent Edward Affleck); "basicamente, é o mecanismo de entrega da informação [cabo, móvel sem fio, radiodifusão ou telefonia] - ao invés do serviço prestado - que dita quais regras serão aplicáveis a cada caso [nos Estados Unidos]" (Susan Ness, pesquisadora do Centro para Relações Transatlânticas da Universidade John Hopkins, School of Advanced International Studies - SAIS), "historicamente, o serviço universal [nos Estados Unidos] vinha definido como acesso ubíquo ao serviço de telefonia de voz, mas o Congresso e a FCC reconhecem a necessidade de transpor o serviço universal de voz para a banda larga" (Susan Ness); "as radiodifusoras [nos Estados Unidos] não pagam ao governo pelo uso dos canais de $6 \mathrm{MHz}$, embora elas tenham somente vagamente definidas suas obrigações de interesse público" (Susan Ness).

Ao final da gestão do ministro Franklin Martins, foi deixado para o governo seguinte da presidenta Dilma Rousseff uma proposta de lei de Revista de Direito, Estado e Telecomunicações, v. 3, n. 1, p. 1-42 (2011)

DOI: https://doi.org/10.26512/lstr.v3i1.21662 
comunicação para revisão do marco regulatório, embora, na posse do novo Ministro das Comunicações, em janeiro de 2011, a atualização do marco regulatório das comunicações não tenha figurado entre as ações prioritárias da nova gestão.

\section{Nova legislatura}

A propósito da transição de governo, o ano de eleições gerais também pode ser analisado sob o enfoque setorial, que serve como um recorte do destino dos candidatos segundo sua atuação política nas telecomunicações. A nova legislatura de 2011 conta com a presença de nomes importantes para o setor, tais como, em ordem alfabética, os deputados Bilac Pinto (PR/MG), Henrique Eduardo Alves (PMDB/RN), Jandira Feghali (PCdoB/RJ), Jorge Bittar (PT/RJ), Julio Semeghini (PSDB/SP), Luiza Erundina (PSB/SP), Miro Teixeira (PDT/RJ), Paulo Bornhausen (DEM/SC) e Paulo Teixeira (PT/SP). Da mesma forma, foram confirmados para o Senado Federal: Eunício Oliveira (PMDB/CE); Flexa Ribeiro (PSDB/PA); Marcelo Crivella (PR/RJ); e Walter Pinheiro (PT/BA). O ex-Ministro das Comunicações, Hélio Costa, perdeu a disputa para governador de Minas Gerais, e o deputado Celso Russomano perdeu a disputa para o Senado Federal por São Paulo. Também deixaram o Congresso, em 2011, o senador Antônio Carlos Júnior (DEM/BA) e os deputados Paulo Henrique Lustosa (PMDB/CE) e Solange Amaral (DEM/RJ).

\section{Concorrência, fusões e aquisições}

O anúncio da licitação da Banda H para SMP 3G - $800 \mathrm{MHz}(12,5+$ $12,5 \mathrm{MHz}), 900 \mathrm{MHz}(2,5+2,5 \mathrm{MHz}), 1,8 \mathrm{GHz}(25+25 \mathrm{MHz}), 1,9 / 2,1$ $\mathrm{GHz}(15+15 \mathrm{MHz})$ e extensão TDD em $1,9 \mathrm{GHz}(5 \mathrm{MHz})$ - gerou reações das operadoras móveis, que temiam a entrada de um novo competidor no mercado de SMP.

O gerente de regulamentação da Superintendência de Serviços Privados (SPV), Bruno Ramos, foi em defesa das regras da licitação da Banda H, lembrando que, desde o ano 2000, a Anatel havia sinalizado sua meta de ter cinco concorrentes no mercado móvel. Próximo à finalização de montagem do edital de licitação da Banda $\mathrm{H}$, o assunto se politizou com o agendamento, em setembro de 2010, de reunião do Comitê Gestor de Políticas de Inclusão Digital (CGPID), da Casa Civil, com a introdução de 
item de pauta de discussão da venda da Banda H. Até, então, a polarização se resumia, de um lado, à posição das operadoras celulares, que pediam a faixa para ampliação de suas redes, e, de outro lado, à posição firmada pela área técnica da Anatel de que a licitação da Banda $\mathrm{H}$ seria uma segunda fase à licitação das demais faixas de terceira geração ocorrida em 2007, destinada a entrada de um quinto competidor no mercado brasileiro na medida em que se a nova Banda $\mathrm{H}$ fosse adquirida pelas operadoras celulares partícipes do edital de 2007, estas ultrapassariam o limite de espectro então estabelecida para cada uma delas.

A discussão passou a contemplar dois fundamentos: o de fomento à competição, mediante entrada de um quinto competidor; e o de garantia da universalização, mediante fortalecimento das operadoras já presentes no mercado, muito embora, em termos técnico-jurídicos, o conceito não se aplicasse a serviços em regime privado, cujo equivalente operacional responde pelo nome de compromissos de abrangência. A inserção, entretanto, do termo universalização, nas discussões do CGPID ligadas ao PNBL, responde a preceitos do PNBL, que continha, em seus documentos de divulgação, como uma de suas ações prioritárias, os "leilões de radiofrequência para prestação de banda larga sem fio, com menor preço e custo de operação".

No segundo Fórum Brasil Conectado, a lista de ações de Nível 1 contemplou a meta de implementação de " $3 \mathrm{G}$ em todos os municípios". Com base nisso, o Secretário de Telecomunicações do Ministério das Comunicações argumentou que, se a meta prioritária do PNBL era universalizar, o edital de Banda $\mathrm{H}$, não deveria ser destinado à entrada de um quinto competidor, na medida em que um novo entrante não teria condições de suportar metas agressivas de penetração. Após reunião de 10 de setembro de 2010 do CGPID, iniciaram-se conversações com a Anatel, sabendo-se que três conselheiros da agência reguladora tendiam a apoiar a entrada de um novo competidor e dois deles estariam mais inclinados à abertura da Banda $\mathrm{H}$ para as operadoras existentes como melhor método para garantia da universalização. Ao final, venceu o posicionamento de abertura a novo competidor no edital de licitação aprovado em setembro de 2010 pelo Conselho Diretor da Anatel com a abertura de todas as frequências livres nas faixas de $800 \mathrm{MHz}, 900 \mathrm{MHz}, 1,8 \mathrm{GHz}, 1,9 \mathrm{GHz}$ e $2,1 \mathrm{GHz}$, resguardada, entretanto, a possibilidade de redivisão das faixas em Revista de Direito, Estado e Telecomunicações, v. 3, n. 1, p. 1-42 (2011)

DOI: https://doi.org/10.26512/lstr.v3i1.21662 
blocos de $5 \mathrm{MHz}$ no caso de não surgirem interessados na licitação nos moldes de valorização de novo competidor, já que a divisão em blocos de 10 $\mathrm{MHz}$ da licitação da Banda $\mathrm{H}$ impedia sua aquisição por operadoras de Serviço Móvel Pessoal (SMP) na maior parte das regiões leiloadas em virtude do teto estabelecido pela Anatel de espectro para cada uma delas. Embora em meio a impugnações judiciais prévias em defesa da necessidade de abertura da licitação às operadoras existentes de SMP como imperativo para massificação da banda larga no país, a licitação da Banda $\mathrm{H}$ e das sobras de frequências do 3G foi concluída em 15 de dezembro de 2010, confirmando-se a expectativa de consolidação de um quinto ator setorial na telefonia móvel no Brasil: a Nextel.

A entrada da Nextel no mercado celular e, portanto, sob os auspícios da regulamentação do Serviço Móvel Pessoal, possibilitou à Anatel dirigir-se à revisão da regulamentação do Serviço Móvel Especializado (SME) [trunking], que se afigurava, até então, no espaço regulatório de atuação da Nextel. A proposta de revisão do SME para torná-lo mais restritivo e distante das utilidades fornecidas pelo SMP, que se encontrava em circulação na Anatel ao final de 2010, era a de retornar o SME à situação vigente quando das primeiras licenças, restringindo-se ao máximo as suas fronteiras a um serviço limitado privado, em que a interconexão com a rede pública é limitada e sua comercialização em massa dificultada.

A previsão regulamentar de que o SMP permite a oferta conjunta do push-to-talk associado a avanços tecnológicos que permitirão o uso eficiente desta utilidade de push-to-talk em frequências de SMP - o chamado High Performance Push-to-Talk (HPTT) -, imuniza a Nextel de efeitos restritivos advindos da intenção de revisão regulatória.

O ano de 2011, portanto, inicia com o anúncio de uma nova concorrente de SMP gestada e fortalecida em política pública de relaxamento da regulamentação do Serviço Móvel Especializado.

No que concerne a fusões e aquisições, por sua vez, frustrada a aquisição da Global Village Telecom (GVT) pela Telefônica, em 2009, o ano de 2010 presenciou o esforço da Telefónica de España em obter o controle acionário da Vivo por intermédio da compra da aquisição do controle acionário de uma de suas controladoras - a Portugal Telecom - mediante oferta de 5,7 bilhões de euros, correspondente a ágio de $145 \%$ sobre a cotação média das ações ordinárias da empresa portuguesa, em maio de 2010. 
As iniciativas da Telefónica refletem sua opção por garantir uma base sólida de telefonia móvel nacional no Brasil ameaçada em 2010 pelo iminente vencimento da golden share do governo de Portugal na Portugal Telecom e a consequente possibilidade de que o controle acionário da Portugal Telecom fosse adquirido por uma das empresas do empresário mexicano Carlos Slim, controlador da Telmex, que, por sua vez, controla a Embratel. Em junho, a oferta de aquisição da Vivo pela Telefónica foi votada na assembléia geral de acionistas da Portugal Telecom e, embora tenha tido o apoio de $74 \%$ de acionistas, o Governo português utilizou a sua golden share para vetar a compra da Vivo pela Telefónica na expectativa do julgamento sobre a validade da golden share do Governo português na Portugal Telecom marcado para 8 de julho de 2010, pelo Tribunal de Justiça da União Europeia. Em 8 de julho de 2010, o Tribunal decidiu pela ilegalidade da golden share detida pelo Governo português na Portugal Telecom. Na sequência de eventos, Oi e Portugal Telecom firmaram acordo, divulgado em fato relevante de final de julho de 2010, para entrada desta última no capital da Oi, prevendo uma aliança industrial entre a Portugal Telecom e a TmarPart e suas controladas representada pela entrada da Portugal Telecom no capital da Telemar Norte Leste S/A, controlada da Oi, em percentual de $22,4 \%$, por meio de participação acionária minoritária nas empresas AG Telecom Participações S/A e LF Tel S/A, pertencentes à Andrade Gutierrez e ao Grupo Jereissati, controladores da Oi, bem como mediante aquisição de ações da holding. Em troca, a Telemar Norte Leste passaria à condição de acionista, em 10\%, da Portugal Telecom, tudo condicionado, entre outras coisas, à alienação da totalidade da participação societária da Portugal Telecom na Brasilcel N.V., acionista controladora da Vivo Participações S.A. Em paralelo, a Telefônica confirmou, em fato relevante publicado na Espanha, em finais de julho de 2010, um acordo de princípios para aquisição da participação da Portugal Telecom na Vivo, no valor de 7,5 bilhões de euros. Em 30 de julho de 2010, a Telefônica deu ingresso ao pedido de anuência prévia na Anatel para assunção de controle da Vivo, que foi aprovado pelo Conselho Diretor da Anatel em 23 de setembro de 2010, mediante certos condicionamentos de metas de abrangência do SMP e de disponibilização de infraestrutura para interiorização de rede de pesquisa avançada, mediante cessão de capacidade de transmissão para uso não-comercial pela Rede Nacional de Ensino e Revista de Direito, Estado e Telecomunicações, v. 3, n. 1, p. 1-42 (2011)

DOI: https://doi.org/10.26512/1str.v3i1.21662 
Pesquisa. Ao final de 2010, o Governo português ainda não havia satisfeito as condições da Comissão Europeia para fazer valer a decisão do Tribunal de Justiça da União Europeia, que, em novembro de 2010, exigiu explicações e concedeu o prazo de dois meses para solução da questão, sob pena de perseguir a aplicação de sanções ao país.

Em outra frente, a Embratel anunciou, em fato relevante de 5 de agosto de 2010, a intenção de adquirir $100 \%$ das ações preferenciais da operadora de TV a Cabo Net Serviços, de que já era acionista, então controlada pela Globo. Foi o primeiro passo para eventual incorporação total da Net pela Embratel, dependendo da aprovação do antigo PL 29/2007, da Câmara dos Deputados, convertido no PLC 116/2010, do Senado Federal, sobre revisão do marco regulatório da mídia por meios confinados.

O Grupo Bandeirantes consolidou sua presença na TV Cidade mediante aquisição de ações, chegando a cerca de $90 \%$ do capital da operadora de TV a Cabo TV Cidade, que atua em 16 cidades brasileiras em oitos estados da federação. A TV Cidade passou, assim, a ter uma estrutura societária composta por dois grupos de mídia nacionais, a Band, com 90\%, e o $S B T$, com $10 \%$. A aquisição conflita com a redação então em tramitação no Senado, do PLC 116/2010, cuja versão em tramitação vedava a operação de acesso confinado por radiodifusoras.

Finalmente, no que diz respeito às relações comerciais de interconexão entre as operadoras fixas e móveis e ao modelo de financiamento da telefonia móvel, a Anatel, em 2010, adotou posição pró-ativa na questão do controle do Valor de Remuneração de Uso de Rede do SMP (VU-M), que é o valor que remunera uma prestadora de SMP pelo uso de sua rede. ${ }^{7} \mathrm{O}$ tão aguardado modelo de custos em processo de contratação pela Anatel não postergou mais a posição da agência de implementar o controle tarifário da VU-M por intermédio da redução progressiva do Valor de Comunicação (VC-1) em 10\%, em 2011, e mais 10\%, em 2012, previamente à aplicação do Índice de Serviços de Telecomunicações (IST) para reajuste dos serviços. A proposta foi aprovada para submissão à consulta pública em 7 de outubro de 2010, pelo Conselho Diretor da Anatel. É bem verdade que a Anatel já inserira regra específica para fixação do VU-M de prestadoras de SMP

${ }^{7}$ Cf. Regulamento de Remuneração pelo Uso de Redes do Serviço Móvel Pessoal SMP, aprovado pela Resolução n. 438, de 10 de julho de 2006. 
consideradas detentoras de poder de mercado significativo (Resoluções n. $480 / 2007$ e 503/2008) a partir de 2010, mas a consulta pública citada foi o primeiro ato concreto de diminuição da VU-M, dada a limitação de que seu valor não ultrapassasse $70 \%$ do valor final da $\mathrm{VC}-1$. A projeção de diminuição progressiva não satisfez as demandas da Superintendência de Serviços Públicos por uma diminuição drástica do valor, nem impressionou uma das grandes interessadas na diminuição - a GVT -, que qualificou a iniciativa de tardia e tímida, mas sinalizou que a Anatel deverá atuar dali em diante de modo pró-ativo no controle tarifário de interconexão de redes móveis.

\section{TV digital: a expansão do padrão ISDB-T e destino da faixa de TV aberta analógica}

O esforço de ampliação da base de países optantes pelo padrão nipobrasileiro de TV digital - o ISDB-T - continuou no ano de 2010. O primeiro semestre do ano, antes da saída de Hélio Costa do Ministério das Comunicações para concorrer ao cargo de governador de Minas Gerais nas eleições gerais, foi destinado a ampliar ao máximo a adoção do padrão ISDB-T no continente rumo ao que ele denominou de sistema latino de televisão. A menina dos olhos de 2010 foi o Uruguai, que, em 27 de dezembro de 2010, declarou oficialmente a adoção do padrão ISDB-T, revendo sua decisão anterior de adoção do padrão europeu de TV digital terrestre. Também era esperada movimentação governamental na sondagem do interesse de Honduras, El Salvador e de cerca de quinze países do continente africano. Com isso, o ano encerrou-se com Japão, Brasil, Perú, Argentina, Chile, Venezuela, Equador, Costa Rica, Paraguai, Filipinas, Bolívia e Uruguai no bloco de países que adotaram o ISDB-T como padrão de TV digital terrestre.

No que concerne, por sua vez, ao destino das radiofrequências liberadas pela transição da TV analógica à digital, um acontecimento dos Estados Unidos importa para as discussões que se seguirão, no Brasil, sobre a destinação do chamado espaço branco [white space]. Em setembro de 2010, a FCC alocou o white space, como faixa não licenciada [unlicensed spectrum], apostando no desenvolvimento de novas tecnologias móveis, em especial, o que chamou de Super Wi-Fi, na esteira da política governamental de resgate da posição estadunidense de engrenagem mundial de descobertas 
e inovação [world's engine of discovery and innovation] e definido como um serviço de maior raio de ação, velocidades e conexões mais confiáveis. Dentre a motivação da decisão por abrir a faixa para dispositivos móveis em formato de espectro não-licenciado, está a declarada intenção de permitir que as novas tecnologias Wi-Fi sejam desenvolvidas nos Estados Unidos e lá patenteadas como uma importante estratégia de fortalecimento da propriedade intelectual na área. ${ }^{8}$

\section{Aspectos jurídicos específicos}

Para além dos aspectos regulatórios dominantes de 2010, outros temas específicos inovaram na estrutura e na interpretação do arcabouço normativo de telecomunicações no Brasil.

\section{Sobreposição de outorgas de modalidades de serviços concedidos}

Em junho de 2010, entendimento da Anatel sobre o cumprimento dos condicionamentos à anuência prévia de aquisição da Brasil Telecom por parte da TELEMAR/Oi serviu para colmatar uma lacuna interpretativa presente no art. 87 da Lei Geral de Telecomunicações (LGT, Lei 9.472/97).

$\mathrm{O}$ art. 87 veda a acumulação por uma operadora da mesma modalidade de serviços concedidos em uma região, localidade ou área, exigindo que as outorgas de modalidades de serviço que gerem o acúmulo de prestação fiquem condicionadas à assunção de compromisso, pela outorgada, de, no prazo de dezoito meses da assinatura do contrato de concessão, transferir a outrem o serviço anteriormente explorado. O prazo para transferência advindo da superposição de outorgas de STFC e dos códigos de seleção de prestadora 14 e 31, quando da aquisição da Brasil Telecom pela TELEMAR/Oi, venceu em julho de 2010. ${ }^{9}$ Embora a BrOi tivesse devolvido

${ }^{8}$ Declaração do Presidente da FCC, Julius Genachowski, intitulada em Second Memorandum Opinion and Order, ET Docket No. 02-380, adotada em 23 de setembro de 2010.

${ }^{9} \mathrm{Cf}$. Ato do Conselho Diretor da Anatel n. 7.828, de 19 de dezembro de 2008, publicado no Diário Oficial da União, Seção 1, de 22 de dezembro de 2008, p. 301 303, correspondente à anuência prévia à aquisição por parte da TELEMAR NORTE LESTE S.A. de ações representativas do controle societário da Invitel S.A., controladora direta da Solpart Participações S.A. e controladora indireta da Brasil Telecom Participações S.A., da Brasil Telecom S.A., da Brasil Telecom Celular S.A., da Brasil Telecom Comunicação Multimídia S.A., da Brasil Telecom Cabos Submarinos LTDA., e da Vant Telecomunicações S.A. 
o código 14 ainda no primeiro semestre de $2009,{ }^{10}$ ela ingressou com pedido de devolução regionalizada em 17 de julho de 2009, aguardando pronunciamento da Anatel a esse respeito enquanto utilizava somente o código 31. Entendimento técnico da Anatel, de junho de 2010, reconheceu a possibilidade de que a Oi pudesse manter os dois códigos de seleção de prestadora, antes detidos pela TELEMAR/Oi e pela Brasil Telecom, desde que realizasse a devolução regionalizada dos códigos sobrepostos, remetendo à Superintendência de Serviços Públicos a solução do que fazer no caso de erro do usuário no uso do código. A possibilidade de se criar um mecanismo automático de redirecionamento desrespeitaria a regra do art. 87, caput da LGT. Prevaleceu, neste caso, o entendimento de que o redirecionamento do usuário para uma gravação que informasse o código correto para sua região não descumpriria o previsto no art. 87, caput da LGT. Em 10 de fevereiro de 2011, a devolução regional da BrOi de códigos sobrepostos para chamadas internacionais foi confirmada por decisão do Conselho Diretor da Agência.

\section{Projeto de Lei de Comunicação Audiovisual de Acesso}

Condicionado: a mídia por meios confinados

O Projeto de Lei, PL 29, que disciplina o provimento de mídia por meios confinados, foi aprovado na Câmara dos Deputados em 2010, como previsto na apresentação do volume anterior desta revista, e convertido em Projeto de Lei da Câmara - PLC 116/2010 -, no Senado Federal.

$\mathrm{O}$ ano de 2010 foi inaugurado com questões jurídicas levantadas por 22 emendas ao PL 29, na Comissão de Constituição e Justiça, da Câmara dos Deputados, na última etapa do processo de apreciação daquela casa, já ultrapassadas a Comissão de Assuntos Econômicos, a Comissão de Defesa do Consumidor e a Comissão de Comunicação. Nas emendas, que foram propostas por 4 deputados - Gerson Peres (PP/PA), Zenaldo Coutinho (PSDB/PA), Regis de Oliveira (PSC/SP) e Paes Landim (PTB/PI) -, questionava-se a constitucionalidade de diversos trechos da proposta, dentre eles, os limites à publicidade da TV por assinatura, a instituição de contribuições para o fomento da atividade audiovisual, as regras de competência da Ancine sobre classificação indicativa, à exigência de

${ }^{10}$ Cf. Ato n. 2.107, de 22 de abril de 2009, do Conselho Diretor da Anatel.

Revista de Direito, Estado e Telecomunicações, v. 3, n. 1, p. 1-42 (2011)

DOI: https://doi.org/10.26512/lstr.v3i1.21662 
aprovação prévia da Ancine para credenciamento de programadores e empacotadores e a previsão de que a produção audiovisual estivesse sujeita à prévia fiscalização e conhecimento da Ancine, todas acusadas de possibilitarem a censura. Ainda as cotas de programação e de canais, a regulação da atividade de programação e empacotamento, os limites ao capital estrangeiro que extrapolassem a radiodifusão e as atividades jornalísticas, dentre outras.

No que diz respeito à regulação em si, o principal questionamento de ordem constitucional recaiu sobre a possibilidade do Estado regular atividade que não se submeteria à concessão pública. A discussão de fundo, entretanto, dada a fragilidade do argumento de impossibilidade de regulação de atividade não-concedida, concentrou-se na afirmação da natureza privada da comunicação e das atividades de produção, programação e empacotamento, bem como na inconstitucionalidade de limites que afastem a sua característica de livre exercício pela sociedade, ressalvados os serviços de acesso condicionado, que têm expressa previsão constitucional regulatória no art. 21, XI da Constituição Federal.

Em 11 de maio de 2010, o PL 29, de 2007, foi aprovado na Comissão de Constituição e Justiça da Câmara dos Deputados (CCJ), com alterações pontuais de emendas modificativas do relator da CCJ - deputado Eduardo Cunha (PMDB/RJ) - na transição das licenças do Serviço Especial de Televisão por Assinatura (TVA) ${ }^{11}$ e no chamado must carry, ${ }^{12}$ mantidos temas polêmicos como o regime de cotas para veiculação de conteúdo nacional na TV por assinatura e a ampliação da competência da Ancine para

${ }^{11}$ Em acordo com o relator, a Anatel regularizou, em março de 2010, a situação das prestadoras de TVA no país, reconhecendo a renovação automática retroativa das licenças e permitindo que as emendas supressivas do relator, na CCJ, fossem transformadas em modificativas para fazer constar que somente as concessões de TVA "em vigor" poderiam ser adaptadas ao novo Serviço de Acesso Condicionado (SAC).

${ }^{12} \mathrm{~A}$ emenda modificativa fixava que a Anatel daria prioridade aos canais religiosos caso as prestadoras do Serviço de Acesso Condicionado (SAC) alegassem dificuldades técnicas ou financeiras no cumprimento da obrigação de distribuição de canais - o must carry -, bem foi acrescido à obrigação de se tornarem disponíveis os canais de distribuição obrigatória, sem ônus ao cliente, o termo "independentemente da tecnologia de distribuição empregada". 
fiscalização das operadoras de TV por assinatura no cumprimento da política de fomento do conteúdo nacional.

A aprovação do projeto, na Câmara dos Deputados, ainda dependia de recurso ao Plenário da Casa, com 74 assinaturas válidas. A desistência de 43 deputados que haviam assinado o pedido garantiu a retirada de pauta do Plenário, permitindo que, em 14 de junho de 2010, o deputado relator Eduardo Cunha (PMDB/RJ) publicasse a redação final do PL 29/2007, aprovado na Comissão de Constituição e Justiça da Câmara dos Deputados.

Iniciada a tramitação no Senado Federal, em 23 de junho de 2010, sob o número PLC 116/2010, apesar da tentativa de aprovação de requerimento do líder do PTB no Senado - senador Gim Argello (PTB/DF) - de votação conjunta pelas comissões pertinentes e do interesse governamental em apressar o seu andamento no Senado Federal, o projeto foi distribuído para análise sucessiva de cinco comissões, quais sejam: a Comissão de Constituição e Justiça (CCJ); a Comissão de Assuntos Econômicos (CAE); a Comissão de Educação (CE); a Comissão de Meio Ambiente e Defesa do Consumidor (CMA); e, finalmente, a Comissão de Ciência e Tecnologia (CCT), que vota o projeto de forma terminativa por se tratar da comissão de mérito.

Após as eleições gerais, em novembro de 2010, os grupos radiodifusores Bandeirantes e SBT se opunham à aprovação do texto de então do PLC 116/2010. De um lado, a Band, como controladora da TV Cidade, e o SBT, como controlador da TV Alphaville de São Paulo, criticavam a previsão de vedação às radiodifusoras de controlarem empresas prestadoras de serviço de TV paga e as limitações impostas pelo projeto à publicidade na TV paga. De outro lado, os mesmos grupos acusavam a redação do PLC 116/2010 de favorecer a Globo no mercado de programação. Ao final, o PLC 116/2010 virou o ano em discussão, com a projeção de ser resgatado pela nova legislatura para tramitação em caráter terminativo em análises sucessivas por todas as comissões temáticas.

\section{Abertura da competição na TV a Cabo e no MMDS}

O Conselho Diretor da Anatel, que esperava dita reestruturação legal para dar andamento aos planos de abertura do mercado de TV a Cabo, antecipou-se à aprovação do projeto e, em maio de 2010, decidiu cautelarmente pela abertura de novas autorizações de TV a Cabo 
independentemente da finalização de tramitação do PL 29, suspendendo a limitação máxima de operadoras por município definida no planejamento para oferta de TV por assinatura de 1997 e reconhecendo, no voto do relator - o conselheiro João Rezende -, que tal abertura já deveria ter sido feita desde 2004, quando a natureza do serviço de TV a Cabo fora esclarecida pelo Tribunal de Contas da União (TCU).

A eficácia da medida, entretanto, ficou condicionada à aprovação de novo Planejamento do Serviço de TV a Cabo e do Serviço de Distribuição de Sinais Multiponto Multicanal (MMDS) pelo Conselho Diretor da Anatel.

Às medidas administrativas de abertura do mercado de TV a Cabo, seguiram-se críticas de uma série de reportagens da TV Bandeirantes, acusando a Anatel de estar beneficiando interesses das empresas de telefonia ao afastar as limitações de planejamento de mercado da TV a Cabo.

Em paralelo, pedidos de informações da Controladoria-Geral da União (CGU) e do TCU evidenciaram a preocupação sobre se a definição do preço administrativo de $\mathrm{R} \$ 9$ mil não estaria contrariando decisões anteriores do TCU sobre TV a Cabo, que exigiam, para retomada de licitações, que fosse elaborada nova metodologia de cálculo do preço mínimo, bem como se o afastamento da exigência de licitação para as novas outorgas não feriria a disciplina da Lei do Cabo.

Em reunião do Conselho Diretor da Anatel, de 2 de setembro de 2010, o voto-vista da conselheira Emília Ribeiro sobre o Planejamento do Serviço de Televisão a Cabo e do Serviço de Distribuição Multiponto Multicanal seguiu o mesmo caminho dos questionamentos do TCU sobre a necessidade de estudos prévios de mercado.

Não obstante, a Resolução $n^{\circ}$ 551, de 3 de dezembro de 2010, aprovada pelo Conselho Diretor da Anatel, veiculou o novo Planejamento do Serviço de TV a Cabo e do Serviço de Distribuição de Sinais Multiponto Multicanal (MMDS) nos moldes propostos pelo conselheiro Jarbas Valente, em que: a) foi derrubado o limite numérico de outorgas de TV a Cabo; b) foi aberto espaço para concretização do entendimento de que empresas coligadas às concessionárias de STFC poderiam prestar serviço de TV a Cabo, fazendo uso da ressalva contida no art. 15 da Lei do Cabo, que trata do caso de inexistência de interessados na prestação de TV a Cabo, interpretação esta reforçada pela retirada, no dia anterior, durante a votação dos novos contratos de concessão de telefonia para o quinquênio 2011-2015, de sua 
cláusula 14.4, que expressamente vedava a posse de licenças de TV a Cabo pelas concessionárias, suas controladas ou coligadas; c) foi fixado o preço administrativo mínimo de $\mathrm{R} \$ 9$ mil para outorga das licenças de TV a Cabo; e, dentre outros assuntos, d) foi prevista a imposição de condicionamentos de cobertura.

As novas licenças de TV a Cabo passaram a depender, portanto, da aprovação de novo regulamento do serviço e dos procedimentos que serão seguidos para as efetivas outorgas projetadas para meados de 2011.

\section{SMP versus MMDS: a disputa pela faixa de 2,5 $\mathrm{GHz}$}

Embora a metodologia de cálculo do preço público de exploração de radiofrequências na faixa de $2,5 \mathrm{GHz}$ a ser cobrado das operadoras de MMDS - valor presente líquido (VPL) das operadoras com base no fluxo de caixa descontado - tivesse sido aprovada em 11 de fevereiro de 2010, a decisão final sobre a mudança de destinação da faixa espectral para detecção da efetiva largura de banda que permaneceria com o MMDS foi aguardada durante todo o primeiro semestre de 2010, municiada de dúvidas e antecipação de posições colocadas na mesa de decisão.

De um lado, a proposta de alteração colocada em consulta pública, que previa $50 \mathrm{MHz}$ da faixa para o MMDS com eventual ampliação para 60 MHz. De outro lado, a proposta de divisão ao meio dos $190 \mathrm{MHz}$ da faixa entre o MMDS e o SMP. Ditas posições principais foram ambientadas em meio a diversas dúvidas: a) a diminuição da faixa do MMDS seria ou não acompanhada por licenças automáticas de SCM? b) as operadoras de MMDS poderiam obter no futuro licenças de SMP para a mesma faixa? c) seria atendida a demanda do Governo Federal de $10 \mathrm{MHz}$ da faixa para inclusão digital? d) qual seria o preço da faixa e com base em quê ele seria calculado?

Todas estas questões se somavam ao fato de que a definição da divisão da faixa de 2,5 GHz entre o MMDS e o SMP contemplava uma intrincada equação de subfaixas, tecnologias e serviços.

Em meados de 2010, a Anatel já caminhava para adotar uma configuração de $50 \mathrm{MHz}$ de espectro TDD acrescidos de mais $20 \mathrm{MHz}$ de espectro FDD para o MMDS, autorizando as operadoras de MMDS a utilizarem as subfaixas para prestação de SMP, restando $120 \mathrm{MHz}$ em FDD para operadoras de SMP. 
Para prestação de serviços 4G LTE-TDD, todavia, a configuração ideal para as operadoras celulares era de $20 \mathrm{MHz}+20 \mathrm{MHz}$, comportando, nos $120 \mathrm{MHz}$ para o SMP, somente três operadoras das quatro operadoras brasileiras de grande porte (Oi, TIM, Vivo e Claro).

No formato esboçado em julho de 2010 pela agência reguladora, de possibilidade de uso de licenças de MMDS para operação de SMP, a Telefônica, recente adquirente da Vivo, poderia suprir sua demanda de espectro para 4G com suas licenças de MMDS já detidas para São Paulo, Rio de Janeiro, Curitiba e Porto Alegre, abrindo-se espaço para o 4G para as quatro grandes empresas de telefonia móvel pessoal.

Finalmente, o assunto da alteração de destinação da faixa de $2,5 \mathrm{GHz}$ chegou ao fim quando, em 5 de agosto de 2010, o Conselho Diretor da Anatel aprovou a republicação do Regulamento sobre Condições de Uso de Radiofrequências nas Faixas de $2.170 \mathrm{MHz}$ a $2.182 \mathrm{MHz}$ e de $2.500 \mathrm{MHz}$ a $2.690 \mathrm{MHz}$ (Res. 544/2010), confirmando a manutenção de $50 \mathrm{MHz}$ ao MMDS no centro da faixa e prevendo que, a partir de 30 de junho de 2013, toda a faixa será destinada ao SMP, bem como também autorizando, pelo prazo de 12 meses, a compra, pelas empresas de MMDS, de licenças de SMP e de SCM.

A decisão também serviu para marcar a retomada da homologação de equipamentos WIMAX pela Anatel, que fora suspensa enquanto se definia o destino da faixa. Manteve-se, todavia, a restrição à mobilidade dos prestadores de SCM via limitações às homologações de equipamentos WIMAX.

A agenda prevista pela Anatel foi de que, em 2010, fossem formuladas as regras do edital que seria publicado em setembro de 2011 para que o leilão ocorra até fevereiro de 2012. A consolidação da faixa para licenças de quarta geração leva à expectativa de reforço das fusões e aquisições no setor, agora envolvendo o espólio das prestadoras de MMDS, não sem críticas advindas de atores como a Sky, que pretendia investir na expansão de banda larga por WIMAX, utilizando-se da faixa do MMDS.

\section{Procedimento decisório do Conselho Diretor da Anatel}

Problemas antigos se agravaram em 2010, como o de estagnação de decisões do Conselho Diretor por pulverização das posições dos conselheiros em votos em separado. 
Os impasses decisórios ocorrem em meio a procedimento decisório composto por apenas uma votação do conjunto da causa, ao invés de se promover à separação entre pontos polêmicos para viabilização da decisão.

O caso GVT versus Vivo sobre o valor da VU-M, por exemplo, teve sua decisão suspensa pelo Conselho Diretor, em reunião de 23 de setembro de 2010, por existirem divergências em dois pontos da causa: a) que parte tem razão; e b) em que data deveria passar a vigorar a decisão de reajuste da VU-M. Se fossem divididos os pontos da causa para votação sucessiva sobre o ganho da causa, de um lado, e sobre a data de implementação, de outro, a decisão não teria resultado em impasse.

\section{A sinonimia entre fundos setoriais e contingenciamento}

O ano de 2010 foi inaugurado com a tradicional prática de contingenciamento da quase totalidade dos fundos setoriais de telecomunicações (FISTEL, FUST e FUNTTEL) na Lei Orçamentária Anual (LOA), inaugurando-se a prática de inserção da maior parte das receitas do Fistel diretamente na conta do Tesouro, o que evidenciou a posição do Governo Federal de que tais recursos não pertenceriam ao setor, mas à União.

Para o FUST, de uma previsão de receita de $\mathrm{R} \$$ 815,767 milhões, somente foram liberados $\mathrm{R} \$ 7,2$ milhões. Por sua vez, o fundo de investimento em pesquisa tecnológica foi corroído, aumentando-se os recursos disponíveis para o Tesouro e destinando-se, dos $\mathrm{R} \$ 327,455$ milhões, apenas R $\$ 52$ milhões para aplicações do fundo contra $\mathrm{R}$ \$ 60,695 milhões do ano anterior.

O desvio para o erário dos tributos vinculados, que compõem a principal fonte de recursos dos fundos setoriais, antecipa o seu já anunciado destino, em vários pronunciamentos governamentais, de se transformarem em moeda de troca para engajamento do setor privado em projetos públicos. No cadafalso, estão a contribuição do FUST e as taxas do FISTEL: é esperar para ver.

O Conselho Editorial 
